\title{
PENGARUH INOVASI PRODUK TERHADAP KEBERHASILAN USAHA
}

\author{
Oleh: \\ Mohammad Ramdan dan Sholihati Amalia \\ Politeknik Negeri Bandung
}

\begin{abstract}
:
Product of innovation is very important to do, especially in running a business. A person who is innovative is usually closer to a new opportunity and is close to a success. Unfortunately innovation is still very minimal done by entrepreneurs. It is proved by the persistence of the product leather jacket with classic models till this time and the lack of growth on the entrepreneurs in Central Industrial Leather Jacket Sukaregang. This study aims to know the influence of product innovation to business success in SMEs leather jacket Sukaregang industrial centers in Garut. In this research, product innovation is the variable $(X)$ and the success of the business is a variable (Y). This research study was quantitative research with the research method used is descriptive method and survey method. By type and method of the study, data analysis used is descriptive analysis, a classic assumption test, regression test, correlation and hypothesis testing. This study is using a nonprobability quota sampling technique to determine the sample. The member sample in this study were 100 respondents who are entrepreneurs in SMEs leather jacket Sukaregang industrial centers in Garut. Results of simple linear regression, obtained by the equation $Y=Y=14.482+0.476 X$ with $R$-Square of 0.475. It shows that product innovation variable effect of $47.5 \%$ against the successive efforts, while the success of the business by $52.5 \%$ influenced by other factors such as quality of human resources, technology competencies, Organizational structure, business culture Culture, Strengths capital, business networks with outsiders. As for external factors such as government (economic policy, political, level of democratization) and non-government (economic system socio-cultural culture, infrastructure conditions and the level of public education) which is not described in this study. Therefore, it can be seen that there are significant product innovation to business success in SMEs leather jacket Sukaregang industrial centers in Garut.
\end{abstract}

\section{Keywords: Product Innovation, Business Success}

